15

\title{
Improving the Competence of Construction Management Consultants to Underpin Sustainable
} Construction in China

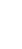

1 - Faculty of Construction Management and Real Estate, Chongqing University, China. Email:

Liguo $\mathrm{SHI}^{1}$, Kunhui $\mathrm{YE}^{2} *$, Weisheng $\mathrm{Lu}^{3}$, and ${\mathrm{Xin} \mathrm{HU}^{4}}^{4}$

582599508@qq.com

(1)

2 - Ph.D., Associate Professor, Faculty of Construction Management and Real Estate, Chongqing

University, China. Email: Kunhui.YE@Gmail.com

3 - Ph.D., Assistant Professor, Department of Real Estate and Construction, the University of Hong Kong.

Email: wilsonlu@hku.hk

4 - Faculty of Construction Management and Real Estate, Chongqing University, China. Email:

$$
\text { hx010203@qq.com }
$$

\section{ABSTRACT}

As a vital component of construction professional services (CPS), construction management consultancy is in nature knowledge-intensive and client-tailored. Although recent studies have acknowledged the increasing role of this subsector of CPS in the attainment of sustainable construction, little attention has been given to the education and training of its main body, namely construction management consultants (CMCs). This study investigated the competence and knowledge structure of CMCs by taking China as an example. Using the methods of interview and questionnaire survey, three key competences of CMCs and the underpinned knowledge structure were identified. The identified competences are personnel quality, onsite practical skills, and continuing professional learning. Underpinned these competences are the knowledge structure composed of a number of disciplines including construction cost planning and control, 

2

civil engineering and construction, engineering contract and law, and construction project management. The research findings lay a solid foundation for future studies to probe into the role of construction management consultants in the area of sustainable construction.

\section{KEYWORDS}

Sustainable construction; construction professional services; knowledge structure; construction education

\section{INTRODUCTION} 6

The construction industry has become both a vehicle for improving the quality of life and an entity that can determine the environmental and social sustainability of development efforts (Plessis, 2007). Such dual roles spell out the significant contribution of the industry to sustainable development. "Sustainable construction”, which means creating and managing a built environment based on resource efficient and ecological principles (Kibert, 1994; Manoliadis, Tsolas, \& Nakou, 2006), outlines the sphere that the construction industry can reach sustainability. After a long evolution in ontology, the seed of "sustainable construction” has matured into a discipline comprising various practical and scientific issues (Hill \& Bowen, 1997). One of the critical issues in the discipline is to determine a proper approach to keep sustainable construction informed in accordance with the hierarchical definitions of construction. In effect, the definition of construction ranges from site activity, project lifecycle, everything related to construction business to the broader process of human settlement creation (Irurah, 2001). Construction activities are executed for constructing physical facilities (i.e., buildings and infrastructures), which will normally last 
49 for decades. The sustainability performance of a physical facility is triggered to a large extent from its

50

51

52 The activity-based nature of sustainable construction calls for adopting creativity, skills, know-how, and construction process, suggesting that sustainable construction is fundamentally activity-specific. modern technologies as many as possible to implement cleaner production (Berggren, 1999). In this sense, sustainable practices make it necessary to improve interdisciplinary collaboration and multi-stakeholder partnerships on construction sites. Construction activities in general involve three primary stakeholders clients, contractors and consultants. The former two stakeholders have attracted much consideration under the heading of sustainable construction, while the subject of consultants has not (Frattari, Dalprà, \& Salvaterra, 2012; Riley, Pexton, \& Drilling, 2003). As a result, there are two questions that have not been explored explicitly, namely what kind of consultants should be and how to educate and to train them effectively with the pace of sustainable development. Consultants provide a wide array of professional services to clients and on behalf of them monitor construction process and interact with contractors. They can exert immense influence on sustainability of to-be-built facilities by providing practical solutions to construction activities, varying from the use of cleaner, more efficient technologies to end-of-pipe management approaches. Furthermore, a full capacity of competitive consultants underscores a sustainable growth of construction industry. For instance, construction-related consultants in Hong Kong have built up a reputation outside the territory, and they have become an imperative factor of the industry's competitiveness (Wong, Ng, \& Chan, 2010).
8

It is widely acknowledged that developing countries have met great challenges of finding a holistic approach to guarantee sustainability in the construction industries (Plessis, 2007; Ye, Shen, \& Zuo, 2013). 1 As one of the largest developing countries in the world, China appears to be a huge construction site 
72 (Chen \& Chambers, 1999; Lu, Ye, Flanagan, \& Jewell, 2013). The challenge of the Chinese construction

73 sector is not only to produce sufficient housing and infrastructures to the society, but also to do it in a

74

75

76

77

78

79

80

81

82

83

84

85

86

87

88

89

90

91

92

93

94

95

socially and ecologically responsible way. There is an urgent need to address the aforementioned two questions in China's construction industry wherein sustainability challenges have been aware of. Recent years have witnessed special academic attention given to the evaluation of engineering consultants' capabilities (Ng \& Chow, 2004), the performance of engineering consultants (Chow \& Ng, 2007), and sustainable competitive advantages of project management consultants (Betts, 1994). Nonetheless, research works devoted to the competence of construction management consultants (CMCs) are very limited, and they have not pinpointed the ways to manage the competitiveness of CMCs properly in responding to social appeal for sustainable construction. In view of the intricacy of the subject, this paper presents takes an early step to investigate the key competence of CMCs and its underpinned knowledge by taking China as an example. By doing so, the research outcomes can lay a useful foundation for future studies to examine the contribution of CMCs to sustainable construction.

\section{CHARACTERISTICS OF CONSTRUCTION MANAGEMENT CONSULTANCY}

Construction management consultancy is an integral part of construction professional services (CPS) that are created by a set of knowledgeable consultants including architects, engineers, engineer-contractors, architect-engineers, engineer-architects, environmental, planners, and geotechnical engineers, landscape architects (Lu, Ye, Flanagan, \& Jewell, 2013). In the CPS sector, CMCs refer in a different way to those professional organizations and/or individuals that offer a combination of skills as well as strategic and tactical solutions to the construction process. The services of CMCs are characterized by a framework of appropriate disciplines and ethics, and decision-making on construction activities in independent, scientific, and impartial manners (Bowen, Pearl, \& Akintoye, 2007). The wide span of consulting business 
requires CMCs to own multi-disciplinary knowledge and experience such as civil engineering, construction technology, financial management, law, and regulation.

The services of construction-related consulting spread out along some established management procedures, which are usually set forth and can be tailored to satisfy different demands of clients. Alongside this strand, the study by Ezeldin and Abu-Ghazala (2007) unveiled three main steps of a quality management system for design consultants to operate, namely awareness, benchmarking of existing practice, and verifying the validation of consulting model. Previous studies have demonstrated that an efficient consulting procedure enhances the value chain of construction projects by interweaving clients with consultants tightly (Kometa, Olomolaiye, \& Harris, 1996). This gives the suggestion that value engineering is a useful tool for clients to appraise the performance of CMCs, and clients have a profound effect on the performance of construction consulting firms. The effect in the view of Kometa et al. (1994) mirrors the main attributes of clients including financial stability, quality of management, organizational quality of client, past performance, client characteristics, client's duty, and past experience.

There are two approaches for measuring the extent to which consultants are able to provide quality services. One is using a number of firm factors, such as the background of firms, past performance, and the capacity to accomplish the work and project approach (Cheung, Kuen, \& Skitmore, 2002). The other is using some project-related factors, such as design submission number, clarity and comprehensiveness of drawings and documents, quality of design solution, and recommendations for reducing project risks (Chow \& Ng, 2009). However, previous studies have pinpointed that the competitiveness of construction consulting business lies in technical accuracy and overall quality of people (Cheng, Proverbs, \& Oduoza, 2006), and embraces a well-qualified team, a well-defined project approach, and effective communication 
119 (Avila, 1997). As pointed out by Cheung et al. (2001), charismatic and participative leadership dominates 120 the satisfaction of consulting team and eventually affect the performance of consultants. Soft skills such as 121 conscientiousness, initiative, social skills, controllability and commitment have equivalent importance to 122 construction consultants (Ling, Ofori, \& Low, 2000). In a broader angle, the study by Ng and Chow (2004) 123 suggested that consultants have technical capabilities, management capabilities, financial capabilities, and 124 quality assurance and control.

\section{CONSTRUCTION MANAGEMENT CONSULTANCY IN CHINA}

Construction professional services (CPS) in China have undergone gradual changes after the successful development of some mega projects, such as Three Gorge Project and Qinhai-Tibet Railway Project (Lu, Ye, Flanagan, \& Jewell, 2013). The current industrial landscape of CPS in China reflects an accumulative effect of long-time national reform and open-door policies on the construction sector (Lu, Ye, Flanagan, \& Jewell, 2013). There are two major parts of CPS, namely, engineering architecture/design and construction management consultancy. The latter one includes construction supervision, project bidding agency and quantity surveying. As a typical subsector of CPS, CMCs originated from China's construction supervision system introduced to assist clients in improving construction process (Liu, Shen, Li, \& Shen, 136 2004). In this system, construction consulting services are provided by construction supervision firms 137 which employ engineers to supervise contractors' onsite activities. In effect, the growth of China's 138 construction industry has been fuelled by an unfailing inflow of capital investment, advanced technologies 139 and managerial approaches from either advanced countries or developed regions (Ling, Ibbs, \& Cuervo, 140 2005). The participation of foreign production elements has advanced the traditional construction business 141 paradigm to an internationally competitive one. With the increasingly diverse requirements and 
142 expectation of clients, construction supervision has maintained evolution to embrace CMCs.

144 Meanwhile, the sizeable urbanization as well as the emergence of numerous construction projects 145 characterized by complicated technologies and management challenges has yielded tremendous 146 opportunities for CMCs to prosper. According to the Report of New Urbanization in China (Niu, 2012), 147 the urbanization rate of China will sustain an annual growth of 1 per cent until the year of 2020. This 148 means that the Chinese construction industry would be facing a larger demand of housing development. 149 Overwhelming housing demand could stir a rapid growth of construction consulting services. For instance, 150 the subsector of construction cost consultancy has seen the increase of firms' income to RMB 80.685 151 billion and the employees to 237,100 in 2011. Both have an annual growth of over 10 percent in the past 152 few years. In the meanwhile, the ascending complexity of projects and the related construction 153 technologies highlight the importance of a closer involvement of CMCs in project delivery (Baccarini, 154 1996).

156 Previous studies have revealed close involvement of foreign engineering consulting firms in China’s 157 construction industry in recent years (Zhao, Zuo, Zillante, \& Zhao, 2012). As reported, these foreign firms 158 have exhibited a high level of professional capabilities in supplying a lifecycle span of services to 159 marketplace. The services they offer include project briefing, conceptual design, and post-evaluation of 160 project performance (Chang \& Tsai, 2003). By contrast, Chinese CMCs are much more engaged in 161 construction activities by placing the emphasis on project management triangle, namely, time, cost, and 162 quality. They posses little advantage of design and technical innovation abilities, international 163 construction experience, general project management, and financial management (Ling \& Gui, 2009). 164 Another distinctive weakness of CMCs goes to the narrow range of knowledge and services, the lack of 


\section{Preliminary lists}

178

\section{METHODOLOGY}

modern consulting awareness and continuing education and training (Du, 2011).

The quantitative approach was adopted as the main research method of this study. A preliminary list of competence factors and curriculums were formulated using the approaches of literature review and interview with scholars. The competence factors serve to answer the question what kind of CMCs should be, while the proposed curriculums are used to explore the knowledge structure of CMCs and how to train/educate CMCs effectively. Thereafter, a nationwide questionnaire survey was conducted to probe opinions on the preliminary list of key competence and curriculums. Data of the survey were eventually analyzed through the methods of factor analysis and cluster analysis.

According to the Regulation of Chinese Registered Consulting Engineers (2001), a qualified consultant must have professional ethics, positive attitudes towards consulting service, innovative potential, learning skill, construction experience, and teamwork. Part of these competence factors have been echoed in some recent studies (Lu, Ye, Flanagan, \& Jewell, 2013; Yao \& Luo, 2005). These competences of CMCs were well appreciated and summarized in Table 1.

Table 1 A preliminary list of CMCs' competence

\begin{tabular}{c|l|l}
\hline Code & Items & References \\
\hline $\mathrm{I}_{1}$ & Professional ethics & $\begin{array}{l}\text { Yao and Luo (2005), the Regulation of } \\
\text { Chinese Registered Consulting Engineers }\end{array}$ \\
\hline $\mathrm{I}_{2}$ & Attitudes towards consultancy & $\begin{array}{l}\text { Yao and Luo (2005), Wang (2000), the } \\
\text { Regulation of Chinese Registered Consulting } \\
\text { Engineers }\end{array}$ \\
\hline
\end{tabular}




\begin{tabular}{c|l|l}
\hline $\mathrm{I}_{3}$ & Teamwork potential & $\begin{array}{l}\text { Yao and Luo (2005), the Regulation of } \\
\text { Chinese Registered Consulting Engineers }\end{array}$ \\
\hline $\mathrm{I}_{4}$ & Creativity & $\begin{array}{l}\text { The Regulation of Chinese Registered } \\
\text { Consulting Engineers }\end{array}$ \\
\hline $\mathrm{I}_{5}$ & $\begin{array}{l}\text { Ownership, management and delivery } \\
\text { of solutions to clients }\end{array}$ & $\begin{array}{l}\text { Wang (2000), the Regulation of Chinese } \\
\text { Registered Consulting Engineers }\end{array}$ \\
\hline $\mathrm{I}_{6}$ & Interpersonal communication skills & Yao and Luo (2005), Wang (2000) \\
\hline $\mathrm{I}_{7}$ & Information and technology skills & $\begin{array}{l}\text { Wang (2000), the Regulation of Chinese } \\
\text { Registered Consulting Engineers }\end{array}$ \\
\hline $\mathrm{I}_{8}$ & Learning skills & $\begin{array}{l}\text { Wang (2000), the Regulation of Chinese } \\
\text { Registered Consulting Engineers }\end{array}$ \\
\hline $\mathrm{I}_{9}$ & Application skills & Yao and Luo (2005), Wang (2000) \\
\hline $\mathrm{I}_{10}$ & Organization skills & $\begin{array}{l}\text { Wang (2000), the Regulation of Chinese } \\
\text { Registered Consulting Engineers }\end{array}$ \\
\hline
\end{tabular}

186

187

201 Table 2 Disciplines and main curriculums

\begin{tabular}{l|l|l|l|l|l}
\hline Category & Code & Variable & Category & Code & Variable \\
\hline
\end{tabular}




\begin{tabular}{|c|c|c|c|c|c|}
\hline \multirow{8}{*}{ Technology } & $\mathrm{C}_{1}$ & $\begin{array}{c}\text { Civil engineering drawing } \\
\text { (88 hours/5.5 credits) }\end{array}$ & \multirow{6}{*}{ Management } & $\mathrm{C}_{13}$ & $\begin{array}{l}\begin{array}{l}\text { Management science (32 } \\
\text { hours/2 credits) }\end{array} \\
\end{array}$ \\
\hline & $\mathrm{C}_{2}$ & $\begin{array}{l}\text { Construction materials (40 } \\
\text { hours/2.5 credits) }\end{array}$ & & $\mathrm{C}_{14}$ & $\begin{array}{c}\text { Construction project } \\
\text { management (48 hours/3 } \\
\text { credits) }\end{array}$ \\
\hline & $\mathrm{C}_{3}$ & $\begin{array}{c}\text { Civil engineering } \\
\text { surveying (48 hours/3 } \\
\text { credits) }\end{array}$ & & $\mathrm{C}_{15}$ & $\begin{array}{l}\text { Financial management (40 } \\
\text { hours/2.5 credits) }\end{array}$ \\
\hline & $\mathrm{C}_{4}$ & $\begin{array}{l}\text { Building architecture (64 } \\
\text { hours/4 credits) }\end{array}$ & & $\mathrm{C}_{16}$ & $\begin{array}{l}\text { Operational science (40 } \\
\text { hours/2.5 credits) }\end{array}$ \\
\hline & $\mathrm{C}_{5}$ & $\begin{array}{l}\text { Building structure ( } 40 \\
\text { hours/2.5 credits) }\end{array}$ & & $\mathrm{C}_{17}$ & $\begin{array}{c}\text { Accounting (40 hours/2.5 } \\
\text { credits) }\end{array}$ \\
\hline & $\mathrm{C}_{6}$ & $\begin{array}{l}\text { Construction equipments } \\
\text { (32 hours/2 credits) }\end{array}$ & & $\mathrm{C}_{18}$ & $\begin{array}{c}\text { Construction cost planning } \\
\text { and control (48 hours/3 } \\
\text { credits) }\end{array}$ \\
\hline & $\mathrm{C}_{7}$ & $\begin{array}{l}\text { Urban planning ( } 32 \\
\text { hours/2 credits) }\end{array}$ & \multirow{6}{*}{ Law } & $\mathrm{C}_{19}$ & $\begin{array}{c}\text { Economic law (32 hours/2 } \\
\text { credits) }\end{array}$ \\
\hline & $\mathrm{C}_{8}$ & $\begin{array}{c}\text { Civil engineering } \\
\text { construction (56 hours/3.5 } \\
\text { credits) }\end{array}$ & & $\mathrm{C}_{20}$ & $\begin{array}{l}\text { Construction regulations } \\
\text { (32 hours/2 credits) }\end{array}$ \\
\hline \multirow{4}{*}{ Economy } & $\mathrm{C}_{9}$ & $\begin{array}{c}\text { Micro- or macro- } \\
\text { economics (32 hours/2 } \\
\text { credits) }\end{array}$ & & $\mathrm{C}_{21}$ & $\begin{array}{l}\text { Engineering contract and } \\
\text { law ( } 48 \text { hours/3 credits) }\end{array}$ \\
\hline & $\mathrm{C}_{10}$ & $\begin{array}{l}\text { Engineering economics } \\
\text { (48 hours/3 credits) }\end{array}$ & & \multirow{3}{*}{$\mathrm{C}_{22}$} & \multirow{3}{*}{$\begin{array}{l}\text { Administrative regulation } \\
\text { (32 hours/2 credits) }\end{array}$} \\
\hline & $\mathrm{C}_{11}$ & $\begin{array}{c}\text { Banking and insurance (32 } \\
\text { hours/2 credits) }\end{array}$ & & & \\
\hline & $\mathrm{C}_{12}$ & $\begin{array}{l}\text { Statistics (40 hours/2.5 } \\
\text { credits) }\end{array}$ & & & \\
\hline
\end{tabular}

Questionnaire survey

A questionnaire form was formulated on the basis of the items listed in Tables 1 and 2. The questionnaire 207 contains three sections. The first section introduces the objectives and scope of the survey. This section is 208 also used to collect demographic data regarding the respondents’ education background, professional areas, 209 years of work, position, and company names. In the other sections, participants are invited to give 210 opinions on the importance of proposed competences and main curriculums respectively. Respondents are 
211 particularly remaindered to mark the importance level per item by taking into account the principles of 212 sustainable construction. A five-level Likert scale is employed to standardize respondents’ feedbacks, 213 namely 1 - extremely unimportant, 2 - unimportant, 3 - neutral, 4 - important, 5 - extremely important.

215 As the organizations that CMCs attach to scatter widely over the Chinese construction industry, it is quite 216 difficult, if not impossible, to recognize the entire population for this study. Thus, the method of snowball 217 sampling was employed to collect respondents’ opinions. A small pool of initial informants was requested 218 to nominate through their social networks other participants who have the knowledge/experiences of 219 construction consulting. To avoid that those people who have many friends are recruited into the sample, 220 informants were requested to send the questionnaire to those professionals they know in other regions. 221 Invited respondents were encouraged to return their feedbacks by mail and by filling in online 222 questionnaire. Consequently, 134 questionnaires were received. Of all the returned questionnaires, 115 223 were found valid. The participants included 19 executives, 37 project managers, and 59 production line 224 CMCs. The participated respondents distributed over 19 provinces including Guangdong (15), Jiangsu 225 (11), Chongqing (10), Beijing (9), Shanghai (9), Sichuan (9), Shandong (8), Zhejiang (7), Tianjin (6), 226 Fujian (6), and Liaoning (5). Over 60 percent of respondents had four years of work experiences. While it 227 is not easy to appreciate the representativeness of the sample to the population of CMCs in China, the 228 composition of the respondents is useful to avoid prejudice and bias on the survey.

\section{Data analysis}


234 Cronbach's alpha presents the reliability of the collected questionnaire data. With the assistance of SPSS 23516.0 software, it was found that the Cronbach's alpha for the questionnaire data is 0.898, which is larger 236 than the acceptable level 0.7 (Sale, Salter, \& Sharp, 2004; Ye, Shen, \& Tan, 2010). This indicates that the 237 questionnaire scales have high internal consistency and reliability at the 5\% significance level.

$239 \quad$ Factor analysis

241 The key competences of CMCs were extracted on the basis of the ten variables listed in Table 1 using the 242 approach of factor analysis. In the discipline of construction management and economics, this approach 243 has been frequently used to identify a number of uncorrelated factors from some potentially correlated 244 variables (Ye, Li, \& Shen, 2013; Lu, Shen, \& Yam, 2008). Technically, factor analysis is an effective 245 approach to identify the related variables by reducing the dimension of variables into a simplified 246 framework. The simplified framework can provide more useful insights into the reaction of CMCs to the 247 broadening concern of sustainable construction. As shown in Table 3, the value of KMO is 0.869, larger 248 than an acceptable level (0.5). The Bartlett's Test of Sphericity is 580.82 with the significance level of 249 0.000. These coefficients indicate that the collected data are suitable for factor analysis.

251 Table $3 \mathrm{KMO}$ and Bartlett's test

\begin{tabular}{c|c|c}
\hline \multicolumn{2}{c|}{$\begin{array}{c}\text { Kaiser-Meyer-Olkin Measure of } \\
\text { Sampling Adequacy }\end{array}$} & 0.869 \\
\hline \multirow{3}{*}{$\begin{array}{c}\text { Bartlett's Test of } \\
\text { Sphericity }\end{array}$} & $\begin{array}{c}\text { Approx. Chi- } \\
\text { square }\end{array}$ & 580.820 \\
\cline { 2 - 3 } & df & 45 \\
\cline { 2 - 3 } & Sig. & 0.000 \\
\hline
\end{tabular}

253 Results of the factor analysis are listed in Table 4. As given in Table 4, the cumulative contribution 254 percentage is $72.169 \%$, suggesting that the vast majority of variance can be explained by the identified 
255 three factors. In appreciating the attributes and the components, these three factors were renamed 256 personnel quality $\left(\mathrm{F}_{1}\right)$, onsite practical skills $\left(\mathrm{F}_{2}\right)$, and continuing professional learning $\left(\mathrm{F}_{3}\right)$ accordingly.

258 Table 4 Key factors extracted

\begin{tabular}{|c|c|c|c|c|c|}
\hline $\begin{array}{l}\text { Key } \\
\text { Factor }\end{array}$ & Variable & $\begin{array}{l}\text { Factor } \\
\text { Loading }\end{array}$ & $\begin{array}{l}\text { Corrected Item-Total } \\
\text { Correlation }\end{array}$ & $\begin{array}{l}\text { Variance } \\
\text { Explained \% }\end{array}$ & $\begin{array}{c}\text { Total } \\
\text { Variance } \\
\text { Explained \% }\end{array}$ \\
\hline \multirow{5}{*}{$\mathrm{F}_{1}$} & $\mathrm{I}_{3}$ & 0.576 & 0.719 & \multirow{5}{*}{26.787} & \multirow{5}{*}{26.787} \\
\hline & $\mathrm{I}_{4}$ & 0.846 & 0.616 & & \\
\hline & $\mathrm{I}_{5}$ & 0.705 & 0.692 & & \\
\hline & $\overline{\mathrm{I}_{6}}$ & 0.640 & 0.706 & & \\
\hline & $\mathrm{I}_{10}$ & 0.650 & 0.584 & & \\
\hline \multirow{3}{*}{$\mathrm{F}_{2}$} & $\overline{\mathrm{I}_{7}}$ & 0.765 & 0.626 & \multirow{3}{*}{24.475} & \multirow{3}{*}{51.262} \\
\hline & $\mathrm{I}_{8}$ & 0.782 & 0.743 & & \\
\hline & $\mathrm{I}_{9}$ & 0.819 & 0.640 & & \\
\hline \multirow{2}{*}{$\mathrm{F}_{3}$} & $\overline{I_{1}}$ & 0.681 & 0.638 & \multirow{2}{*}{20.907} & \multirow{2}{*}{72.169} \\
\hline & $\mathrm{I}_{2}$ & 0.823 & 0.513 & & \\
\hline
\end{tabular}

Furthermore, the following formula was adopted to calculate the relative importance indices of the ten variables. As a result, the mean values per variable under the headings of the key factors were derived as 263 shown in Table 5.

Relative importance index $=\sum(a X) * 100 / 5$

Where $a$ is the score of a variable judged by respondents. $X=n / N$, where $n$ refers to the number of 268 questionnaires that have same scores for a certain variable, and $\mathrm{N}$ is the number of valid questionnaires.

270 Table 5 Importance indices of key factors

\begin{tabular}{c|c|c|c|c}
\hline $\begin{array}{c}\text { Key } \\
\text { Factor }\end{array}$ & Variable & $\begin{array}{c}\text { Relative importance } \\
\text { index }\end{array}$ & Rank & $\begin{array}{c}\text { Relative importance } \\
\text { index }^{\text {a }}\end{array}$ \\
\hline $\mathrm{F}_{1}$ & $\mathrm{I}_{3}$ & 90.26 & 2 & 87.97 \\
\hline
\end{tabular}




\begin{tabular}{l|c|c|c|c|}
\hline \multirow{4}{*}{} & $\mathrm{I}_{4}$ & 85.22 & 7 & \multirow{2}{*}{} \\
\cline { 2 - 4 } & $\mathrm{I}_{5}$ & 88.17 & 4 \\
\cline { 2 - 4 } & $\mathrm{I}_{6}$ & 87.83 & 5 \\
\cline { 2 - 4 } & $\mathrm{I}_{10}$ & 88.35 & 3 & \\
\hline \multirow{3}{*}{$\mathrm{F}_{2}$} & $\mathrm{I}_{7}$ & 81.39 & 10 & \multirow{2}{*}{83.48} \\
\cline { 2 - 4 } & $\mathrm{I}_{8}$ & 86.78 & 9 & \multirow{2}{*}{8} \\
\cline { 2 - 4 } & $\mathrm{I}_{9}$ & 82.26 & 1 & \multirow{2}{*}{88.17} \\
\hline \multirow{2}{*}{$\mathrm{F}_{3}$} & $\mathrm{I}_{1}$ & 92.00 & 8 & \\
\cline { 2 - 4 } & $\mathrm{I}_{2}$ & 84.35 & & \multicolumn{2}{c}{} \\
\hline
\end{tabular}

271

272

273

274

275

276

277 278

279

280

281

282

283

284

$\mathrm{a}$ - mean values of the variables included.

\section{Cluster analysis}

The mean value per variable was used to calculate the importance levels of curriculums. Based on the mean values, the curriculums were ranked to present the importance levels as shown in Table 6 .

Table 6 Survey results of the curriculums

\begin{tabular}{c|c|c|c|l|l|l|l|}
\hline Code & $\begin{array}{l}\text { Mean } \\
\text { value }\end{array}$ & $\begin{array}{c}\text { Standard } \\
\text { deviation }\end{array}$ & Rank & Code & $\begin{array}{l}\text { Mean } \\
\text { value }\end{array}$ & $\begin{array}{l}\text { Standard } \\
\text { deviation }\end{array}$ & Rank \\
\hline $\mathrm{C}_{18}$ & 4.270 & 0.882 & 1 & $\mathrm{C}_{6}$ & 3.626 & 0.821 & 12 \\
\hline $\mathrm{C}_{8}$ & 4.235 & 0.902 & 2 & $\mathrm{C}_{22}$ & 3.617 & 1.014 & 13 \\
\hline $\mathrm{C}_{21}$ & 4.235 & 0.994 & 3 & $\mathrm{C}_{13}$ & 3.574 & 1.018 & 14 \\
\hline $\mathrm{C}_{14}$ & 4.191 & 0.907 & 4 & $\mathrm{C}_{19}$ & 3.565 & 1.027 & 15 \\
\hline $\mathrm{C}_{20}$ & 4.087 & 1.022 & 5 & $\mathrm{C}_{3}$ & 3.504 & 0.912 & 16 \\
\hline $\mathrm{C}_{1}$ & 4.052 & 0.877 & 6 & $\mathrm{C}_{9}$ & 3.357 & 0.870 & 17 \\
\hline $\mathrm{C}_{5}$ & 4.026 & 0.863 & 7 & $\mathrm{C}_{7}$ & 3.296 & 0.917 & 18 \\
\hline $\mathrm{C}_{4}$ & 3.965 & 0.888 & 8 & $\mathrm{C}_{16}$ & 3.278 & 0.978 & 19 \\
\hline $\mathrm{C}_{10}$ & 3.948 & 0.887 & 9 & $\mathrm{C}_{17}$ & 3.226 & 0.956 & 20 \\
\hline $\mathrm{C}_{2}$ & 3.826 & 0.901 & 10 & $\mathrm{C}_{12}$ & 3.165 & 1.017 & 21 \\
\hline $\mathrm{C}_{15}$ & 3.643 & 0.993 & 11 & $\mathrm{C}_{11}$ & 3.104 & 0.862 & 22 \\
\hline & & & & & \\
\hline
\end{tabular}

Data in Table 6 were detected to identify whether the curriculums were similar in terms of their importance to the key competence. If this similarity does exist, the curriculums described previously can be integrated into fewer groups. Integration could simplify analysis of the knowledge structure of CMCs. 
285 For this purpose, the technique of cluster analysis was then employed to look at CMCs' knowledge 286 structure through the software package of SPSS 16.0. Cluster analysis is a statistical technique that 287 classifies observations into common sets or groups (Ketchen \& Shook, 1996). The derived importance 288 index per curriculum is shown in Table 7 and these curriculums were further classified into four categories.

290 Table 7 Results of the cluster analysis

\begin{tabular}{lll}
\hline Code & Items & $\begin{array}{l}\text { Importance } \\
\text { level }\end{array}$ \\
\hline $\mathrm{C}_{18}$ & Construction cost planning and control & 4.270 \\
$\mathrm{C}_{8}$ & Civil engineering construction & 4.235 \\
$\mathrm{C}_{21}$ & Engineering contract and law & 4.235 \\
$\mathrm{C}_{14}$ & Construction project management & 4.191 \\
\hline $\mathrm{C}_{20}$ & Construction regulations & 4.087 \\
$\mathrm{C}_{1}$ & Civil engineering drawing & 4.052 \\
$\mathrm{C}_{5}$ & Building structure & 4.026 \\
$\mathrm{C}_{4}$ & Building architecture & 3.965 \\
$\mathrm{C}_{10}$ & Engineering economics & 3.948 \\
$\mathrm{C}_{2}$ & Construction materials & 3.826 \\
\hline $\mathrm{C}_{15}$ & Financial management & 3.643 \\
$\mathrm{C}_{6}$ & Construction equipment & 3.626 \\
$\mathrm{C}_{22}$ & Administrative regulation & 3.617 \\
$\mathrm{C}_{13}$ & Management science & 3.574 \\
$\mathrm{C}_{19}$ & Economic law & 3.565 \\
$\mathrm{C}_{3}$ & Civil engineering surveying & 3.504 \\
\hline $\mathrm{C}_{9}$ & Micro- or macro- economics & 3.357 \\
$\mathrm{C}_{7}$ & Urban planning & 3.296 \\
$\mathrm{C}_{16}$ & Operational science & 3.278 \\
$\mathrm{C}_{17}$ & Accounting & 3.226 \\
$\mathrm{C}_{12}$ & Statistics & 3.165 \\
$\mathrm{C}_{11}$ & Banking and insurance & 3.104 \\
\hline & &
\end{tabular}

291

292

293

FINDINGS AND DISCUSSION

294

295 Findings of the research were derived by summarizing the data analysis results shown in Tables 4 and 7.

296 An in-depth face-to-face interview with a director of a local large construction consulting enterprise, the 
297 chairperson and the secretariat of the aforementioned advisory panel was afterwards conducted to discuss 298 the research findings. The director is a senior CMC with work experience of over twenty-five years. 299 Feedbacks of them were cited to verify the research findings.

\section{CMCs’ key competences}

Table 5 summarizes the results of ten competences considered by the respondents. Interestingly, the survey results show that the importance indices of personnel quality $\left(\mathrm{F}_{3}\right)$, onsite practical skills $\left(\mathrm{F}_{1}\right)$, and continuing professional learning $\left(\mathrm{F}_{2}\right)$ are $88.17,87.97$ and 83.48 respectively. This signifies a high importance level of the key factors and the priority of the factor $\mathrm{F}_{3}$ over the key competence of CMCs.

307 The components of $\mathrm{F}_{3}-$ Variables $\mathrm{I}_{1}$ (professional ethics) and $\mathrm{I}_{2}$ (attitudes towards consultancy) account 308 for the vital importance of the key factor. Professional ethics $\left(\mathrm{V}_{1}\right.$ ) basically refers to the personal and 309 corporate standards of behaviors expected of professionals, and prudence and resistance to corruption are 310 the principal part of professional ethics (Suresh \& Raghavan, 2005). The identification of this variable 311 concurs with previous studies on the attribute of CPS that CMCs should have the obligation of 312 confidentiality and carry out construction services in a fair, independent and professional manner (Bowen, 313 Pearl, \& Akintoye, 2007). As pointed out by the Chairperson, with the increase in population and diversity 314 of practitioners' education backgrounds, CMCs in China have been confronting with considerable 315 challenges with professional ethics. The situation has not been improved significantly (Ling \& Lim, 2010), 316 although professional societies in construction engineering, such as China Registered Constructor 317 Association, have circulated some guidelines for its members to behave accordingly. In addition, Variable $318 \mathrm{I}_{2}$ satisfies the Regulation of Chinese Registered Consulting Engineers which requires CMCs to have 319 positive attitude towards consulting services. As pointed out by the interviewed director, construction 
321 behave proactively to help clients manage construction process to satisfy the requirement of sustainable 322 construction. Therefore, this key competence $\left(F_{3}\right)$ stresses that more efforts are needed to improve the 323 personality of consultants to underpin the sustainable growth of the construction industry.

324 The factor of onsite practical skills $\left(\mathrm{F}_{1}\right)$ is appreciated as the second key competence of CMCs. $\mathrm{F}_{1}$ 325 elaborates the capabilities that CMCs must own in processing construction management consultancy on 326 project sites. The survey results given in Table 4 show that this key competence is composed of teamwork 327 potential $\left(\mathrm{I}_{3}\right)$, organization skills $\left(\mathrm{I}_{10}\right)$, ownership, management and delivery of solutions to clients ( $\left.\mathrm{I}_{5}\right)$, 328 interpersonal skills $\left(\mathrm{I}_{6}\right)$, and creativity $\left(\mathrm{I}_{4}\right)$. As pointed out by the interviewed director, these five variables 329 accord with the requirements of CMCs as stipulated in the Regulation of Chinese Registered Consulting 330 Engineers. Specifically, Variable $I_{3}$ has the importance level of 90.26, suggesting that efficient 331 cooperation with project team members deserves much attention in the way towards sustainability. The 332 priority of teamwork potential is probably due to the fact that a vast majority of CMCs, who have a 333 narrow range of knowledge and limited practical skills, are able to create quality services by working 334 closely in a team (Du, 2011). Variables $\mathrm{I}_{10}$ and $\mathrm{I}_{5}$ signify the necessity of CMCs to organize and to 335 coordinate construction works efficiently. Variable $\mathrm{I}_{6}$ highlights the value of communication skills of 336 CMCs in comprehending clients' demands and delivering effective solutions in due time. Variable $\mathrm{I}_{4}$ 337 reveals that both differentiation strategies and innovative thinking are the ingredient of CMCs' 338 competence to form competitive advantages, and it echoes the National Plan of Construction Consulting 339 Services (2010-2015) on the demand of "increasing inputs into research and development of theories for 340 construction management consultancy”.

342 Continuing professional learning $\left(\mathrm{F}_{2}\right)$ is the third key competence of CMCs. The importance of this factor 343 has been recognized in previous studies. The study by Chan \& Chan (2002) opined that continuing 
344 professional development has been receiving increasing attention in recent decades, and China’s 345 professionals are required to establish life-long learning. The work by Ling and Gui (2009) found that that 346 the knowledge of CMCs in China is not up-to-date. The interviewed secretariat pointed out that to 347 improve the knowledge of CMCs, China CMC Association has established some programs of Continuing 348 Professional Development (CPD) for practitioners to implement with the emphasis on economics, law, 349 managerial and technical knowledge, learning and skills, and ethics. As indicated in Tables 4 and 5, I8 350 (learning skills), $\mathrm{I}_{9}$ (application skills), and $\mathrm{I}_{7}$ (information and technology skills) are the sub-factors of 351 this key competence $\left(\mathrm{F}_{2}\right)$. In effect, with the globalization of world economy, many new concepts such as 352 lifecycle management, building information modeling, and green building are penetrating the minds of 353 construction practitioners. To provide quality services, CMCs ought to keep learning new knowledge and 354 update their knowledge structure constantly.

\section{Knowledge structure of CMCs on the strand of curriculums}

CMCs are knowledge providers to clients to manage construction activities on site. The richness in 359 knowledge enables CMCs to interact with business partners and manage widespread construction 360 activities. In this study, the knowledge structure of CMCs can be illustrated through identifying the key 361 curriculums indicated by the respondents. As shown in Table 7, the higher the index, the more important 362 the curriculum will be. With this in mind, it was found that construction cost planning and control $\left(\mathrm{C}_{18}\right)$ 363 precedes over other curriculums in the domain of CMCs' knowledge. According to Porter (1980), cost 364 leadership means being less expensive than competitors in the entire range of a company’s activities. The 365 strategy of cost leadership is apt for both extremely competitive business and fairly uniform project works 366 (Warszawski, 1996). Therefore, this factor spells out the expectation and requirements posed by clients on 
CMCs to own the cost leadership of construction project management. As revealed by the Chairperson, civil engineering and construction $\left(\mathrm{C}_{8}\right)$ is a key technical curriculum in China's university construction management education. In the study, this factor ranks second in contributing to CMCs' key competence. The identification of the factor aligns with the study by Tang et al. (2003) on that technology is the backbone of construction consulting service (Tang, Lu, \& Chan, 2003).

Engineering contract and law $\left(\mathrm{C}_{21}\right)$ ranks third, implying that clients expect CMCs to engage in managing intricate business relationships which are dominated by stakeholders via the nexus of contracts. As pointed out by the interviewed director, the main reason for this factor is probably due to the fact that CMCs have poor awareness of contract and legislation. Understanding the fundamental business rules and practices in contract administration and procuring necessary resources at a lower price and deliver them construction site as scheduled is one of key responsibilities of CMCs. Construction project management $\left(\mathrm{C}_{14}\right)$ ranks fourth, indicating that CMCs need to employ specialized tools and techniques to solve problems related to schedule, budget, quality and other goals. Interestingly, civil engineering drawing $\left(\mathrm{C}_{1}\right)$ occupies a higher position in the knowledge structure of CMCs, highlighting the fundamental skills that CMCs need to acquire, such as computer aided design (CAD). This meets the opinion of the secretariat that the construction industry is labor-intensive with relatively low levels of knowledge; the application of new information technologies has achieved great progress in China.

\section{Improving key competence for sustainable construction}

Sustainable construction has been appreciated as a new promising development in the industry (Ye, Shen, \& Zuo, 2013; Lu, Ye, Flanagan, \& Jewell, 2013), although the practices are still in an infancy stage (Lu, 
Ye, Flanagan, \& Jewell, 2013). As discussed above, the discipline of sustainable construction details a body of knowledge comprised of principles, approaches and techniques. According to the Chairperson interviewed in this study, the tenet of sustainable construction has posed great challenges onto the traditional university curriculum setting in China, necessitating the establishment of a new system that can address the problems of sustainable construction. The key competence of CMCs identified in the study includes personnel quality, onsite practical skills and continuing professional learning. While these three competences shed light on construction management programs in the higher education, they illustrate the direction that CMCs would be trained in the industry. Construction consulting firms are thus recommended to organize regular trainings to get frontline CMCs familiarized with multidisciplinary practices and deepening inter-professional collaboration on sustainable construction. Thereby, CMCs can assist the client better in managing sustainable construction business.

The key competences, which support CMCs to undertake predefined consulting services, usually result from a specific set of skills or production techniques that deliver additional values to clients. To survive from fierce business competition, an organization needs to protect its key competence and knowledge by following certain mechanisms, processes and systems (Chen, 2005). In this study, the knowledge learning of CMCs goes to the acquisition of new technology, new capability and effective leadership in the area of sustainable construction. The formulation of competence is exactly a process of knowledge creation and knowledge acquisition within construction consulting firms. Both the adaptive learning capability and a process of learning-by-doing deserve much attention. As revealed, the education of sustainable construction is mainly concerned with the subjects of construction cost planning and control, civil engineering and construction, engineering contract and law, construction project management, and civil engineering drawing. These main curriculums echo with the four pillars of sustainable construction - 
413 social, economic, biophysical and technical (Hill \& Bowen, 1997). Meanwhile, CMCs have the 414 importance of possessing the knowledge of not only the construction process but also the development of 415 the industry, in particular the availability of new sustainable technology and green materials to adhere to 416 the principle of sustainable construction.

418 CONCLUSIONS

420 The agenda of urbanization in China has brought construction management consultants (CMCs) favorable 421 development opportunities to serve clients better in line with the principle of sustainable construction. 422 While the industrial size is expanding, construction consulting firms in China are competing strongly for 423 competent CMCs to provide quality services to marketplace. The key competence of CMCs identified in 424 this study comprises personnel quality, onsite practical skills, and continuing professional learning. 425 Overall, the key competences accord with the attributes of construction consulting services as well as the 426 increasingly diversified demands of construction clients with respect to sustainability. While the findings 427 of this study could support the education/training of construction professionals in China, CMCs in the 428 industry are recommended to appraise their personal competitiveness to meet the requirement of 429 sustainable construction. The knowledge structure of CMCs ranges from construction technology, 430 management science, economics, to legislation. The identification of knowledge structure favors 431 construction consulting firms to train and to educate their human resources accordingly. The research 432 findings are useful for China's construction practitioners to improve professional services to guarantee 433 sustainable industry growth at the early development stage. In considering that key competences are the 434 firm's primary expertise and forms a source of sustained competitive advantage, it is implied that foreign 435 construction consulting firms which are entering or to enter China’s construction industry might consider 
436 these key competences and the underpinned knowledge structure. This paper presents some early results 437 of a two-step research which aims to orient the competence of CMCs towards sustainable construction. 438 The research findings pave the way for the next research to look at the relationship between the 439 competence factors and the knowledge structure, and the education of CMCs for the improvement of 440 sustainable construction.

442 REFERENCES

443

444 E.A. Avila, Demystifying the Local Agency Procurement and Selection Process for Professional 445 Engineering Consultant Services, Journal of Management in Engineering, 13 (1997) 92-95.

446 D. Baccarini, The Concept of Project Complexity - A Review, International Journal of Project 447 Management, 14 (1996) 201-204.

448 B. Berggren, Industry's Contribution to Sustainable Development, Building Research \& Information, 27 449 450 (1999) 431-435.

M. Betts, Sustainable Competitive Advantage for Project-management Consultants, Journal of Management in Engineering, 10 (1994) 43-51.

452 P. Bowen, R. Pearl, \& A. Akintoye, Professional Ethics in the South African Construction Industry, 453 Building Research \& Information, 35 (2007) 189-205.

454 E.H.W. Chan, \& A.T.S. Chan, Development of Professional System in the Construction Industry of China, 455 Journal of Construction Research, 3 (2002) 271-284.

456 A. Chang, \& Y. Tsai, Engineering Information Classification System, Journal of Construction Engineering 457 and Management, 129 (2003) 454-460.

458 J.J. Chen, \& D. Chambers, Sustainability and the Impact of Chinese Policy Initiatives upon Construction, $459 \quad$ Construction Management and Economics, 17 (1999) 679-687. 
J. Cheng, D.G. Proverbs, \& C.F. Oduoza, The Satisfaction Levels of UK Construction Clients Based on the Performance of Consultants: Results of a Case Study, Engineering, Construction and Architectural Management, 13 (2006) 567-583.

F.K.T. Cheung, J.L.F. Kuen, \& M. Skitmore, Multi-criteria Evaluation Model for the Selection of Architectural Consultants, Construction Management and Economics, 20 (2002) 569-580.

S.O. Cheung, S.T. Ng, K.C. Lam, \& W.M. Yue, A Satisfying Leadship Behaviour Model for Design Consultants, International Journal of Project Management, 19 (2001) 421-429.

L.K. Chow, \& S.T. Ng, A Fuzzy Gap Analysis Model for Evaluating the Performance of Engineering Consultants, Automation in Construction, 16 (2007) 425-435.

L.K. Chow, \& S.T. Ng, Delinerting the Performance Standards of Engineering Consultants at Design Stage, Construction Management and Economics, 28 (2009) 3-11.

F.J. Du, Analysis of the Development of the Management Consulting Industry in China, Journal of ShanXi Finance and Economics University, 33 (2011) 27 (In Chinese).

A.S. Ezeldin, \& H. Abu-Ghazala, Quality Management System for Design Consultants: Development and Application on Projects in the Middle East, Journal of Management in Engineering, 23 (2007) 7587.

A. Frattari, M. Dalprà, \& G. Salvaterra, The Role of the General Contractor in Sustainable Green Buildings: The Case Study of Two Buildings in the Leed Certification in Italy, International Journal for Housing Science and Its Applications, 36 (2012) 139-149.

R.C. Hill, \& P.A. Bowen, Sustainable Construction: Principles and a Framework for Attainment, Construction Management and Economics, 15 (1997) 223-239.

D.K. Irurah, Agenda for Sustainable Construction in Africa. in: Editor (Ed)^(Eds), Book Agenda for Sustainable Construction in Africa. , Publisther, 2001. 
D.J. Ketchen, \& C.L. Shook, The Application of Cluster Analysis in Strategic Management Research: An Analysis and Critique, Strategic Management Journal, 17 (1996) 441-458.

C.J. Kibert, Final Session of First International Conference of CIB TG 16 on Sustainable Construction, in: Editor $(\text { Ed })^{\wedge}($ Eds), Book Final Session of First International Conference of CIB TG 16 on Sustainable Construction, Publisther, 1994.

S.T. Kometa, P.O. Olomolaiye, \& F.C. Harris, A Review of Client-Generated Risks to Project Consultants, International Journal of Project Management 14 (1996) 273-279.

S.T. Kometa, P.O. Olomolaiye, \& F.C. Harris, Attributes of UK Construction Clients Influencing Project Consultants' Performance, Construction Management and Economics, 12 (1994) 433-443.

F.Y.Y. Ling, G. Ofori, \& S.P. Low, Importance of Design Consultants' Soft Skills in Design-Build Projects, Engineering, Construction and Architectural Management, 7 (2000) 389-398.

F.Y.Y. Ling, \& Y. Gui, Strengths, Weaknesses, Opportunities, and Threats: Case Study of Consulting Firms in Shenzhen, China, Construction Engineering and Management, 135 (2009) 628-636.

F.Y.Y. Ling, C.W. Ibbs, \& J.C. Cuervo, Entry and Business Strategies Used by International architectural, Engineering and Construction Firms in China, Construction Management and Economics, 23 (2005) 509-520.

F.Y.Y. Ling, \& S.H. Lim, Improving Export Performance of Contractors from China, Engineering, Construction and Architectural Management, 17 (2010) 581-597.

G. Liu, Q. Shen, H. Li, \& L. Shen, Factors Constraining the Development of Professional Project Management in China's Construction Industry, International Journal of Project Management, 22 (2004) 203-211.

W. Lu, L. Shen, \& M.C.H. Yam, Critical Success Factors for Competitiveness of Contractors: China Study, Journal of Construction Engineering and Management, 134 (2008) 972-982. 
506 W. Lu, K. Ye, R. Flanagan, \& C. Jewell, Developing Construction Professional Services in the 507 International Market: A SWOT Analysis of China, Journal of Management in Engineering, 29 $508 \quad$ (2013) 302-313.

509 O. Manoliadis, I. Tsolas, \& A. Nakou, Sustainable Construction and Drivers of Change in Greece: A 510 Delphi Study, Construction Management and Economics, 24 (2006) 113-120.

511 S.T. Ng, \& L.K. Chow, Evaluating Engineering Consultants' General Capabilities during the Pre-selection 512 Process - A Hong Kong Study, Engineering, Construction and Architectural Management, 11 $513 \quad$ (2004) 150-158.

514 W. Niu, The Report of New Urbanization in China 2012, Science Press, 2012.

515 C.D. Plessis, A Strategic Framework for Sustainable Construction in Developing Countries, Construction $516 \quad$ Management and Economics, 25 (2007) 67-76.

517 M. Porter, Competitive Strategy: Techniques for Analysing Industries and Competitors, Free Press, 1980. 518 D. Riley, K. Pexton, \& J. Drilling, Procurement of Sustainable Construction Services in the United States: 519 The Contractor's Role in Green Buildings, Industry and Environment, 26 (2003) 66-69.

520 J.T. Sale, S.B. Salter, \& D.J. Sharp, Advances in International Accounting, Elservier Ltd., 2004.

521 J. Suresh, \& B. Raghavan, Professionals ethics: Values and ethics of professionals, Chand \& Co. Ltd., $522 \quad$ New Delhi, India, 2005.

523 S. Tang, M. Lu, \& Y. Chan, Achieving Client Satisfaction for Engineering Consulting Firms, Journal of $524 \quad$ Management in Engineering, 19 (2003) 166-172.

525 J.M.W. Wong, S.T. Ng, \& A.P.C. Chan, Strategic Planning for the Sustainable Development of the 526 Construction Industry in Hong Kong, Habitat International, 34 (2010) 256-263.

527 T.P. Yao, \& S.M. Luo, Reform of Engineering Consulting Education in 21st Century, China Economist, 7 $528 \quad$ (2005) 98-99. 
529 K. Ye, B. Li, \& L. Shen, Key Factors Considered in Compiling Tender Prices for China's Public Project $530 \quad$ Works, Journal of Management in Engineering, 29 (2013) 206-215.

531 K. Ye, L. Shen, \& Y. Tan, Response Strategies to the Competition in the Chinese Constructon Market, $532 \quad$ Construction Management and Economics, 28 (2010) 115-124.

533 K.Ye, L. Shen, \& J. Zuo, Utilizing the Linkage between Domestic Demand and the Ability to Export to 534 Achieve Sustainable Growth of Construction Industry in Developing Countries, Habitat $535 \quad$ International, 38(2013) 135-142.

536 A. Warszawski, Strategic Planning in Construction Companies, Construction Engineering and 537 Management, 122 (1996) 133-140

538 Z.Y. Zhao, J. Zuo, G. Zillante, \& X.J. Zhao, Foreign Architectural and Engineering Design Firms’ 539 Competitiveness and Strategies in China: A Diamond Model Study, Habitat International, 36 $540 \quad$ (2012) 362-370. 